\title{
PENGARUH INFLASI DAN LEVERAGE TERHADAP PROFITABILITAS DAN RETURN SAHAM PADA PERUSAHAAN MANUFAKTUR DI BURSA EFEK INDONESIA
}

\author{
I Gede Putra Adyatmika ${ }^{1}$ \\ I Gusti Bagus Wiksuana² \\ ${ }^{1,2}$ Fakultas Ekonomi dan Bisnis Universitas Udayana (Unud), Bali, Indonesia \\ Email: putra.adyatmika@gmail.com
}

\begin{abstract}
ABSTRAK
Tujuan dari penelitian ini adalah untuk mengetahui pengaruh dari Inflasi dan Leverage terhadap Profitabilitas dan Return Saham serta mengetahui kemampuan Profitabilitas dalam memediasi pengaruh Inflasi dan Leverage terhadap Return Saham pada perusahaan manufaktur di Bursa Efek Indonesia. Penelitian ini menggunakan saham-saham perusahaan sektor manufaktur sebagai objek penelitian. Sampel penelitian diambil dengan metode proportional random sampling dan jumlah sampel penelitian ini sebanyak 31 perusahaan yang diperoleh dari website Bursa Efek Indonesia dari tahun 2012 sampai dengan tahun 2016. Pengujian hipotesis dilakukan dengan menggunakan metode analisis jalur (Path Analysis) dengan bantuan program SPSS. Hasil dari penelitian menemukan bahwa (1) Inflasi berpengaruh negatif dan signifikan terhadap Return Saham, (2) Leverage berpengaruh negatif dan signifikan terhadap Return Saham, (3) Profitabilitas berpengaruh positif dan signifikan terhadap Return Saham, (4) Inflasi berpengaruh negatif dan tidak signifikan terhadap Profitabilitas, (5) Leverage berpengaruh negatif dan signifikan terhadap Profitabilitas, (6) Profitabilitas tidak mampu memediasi pengaruh Inflasi terhadap Return Saham, (7) Profitabilitas mampu memediasi pengaruh Leverage terhadap Return Saham.
\end{abstract}

Kata kunci: Inflasi, Leverage, Profitabilitas, Return Saham.

\begin{abstract}
The purpose of this study is to determine the effect of Inflation and Leverage on Profitability and Stock Return as well as knowing the ability of Profitability in mediating the influence of Inflation and Leverage to Stock Return at manufacturing companies in Indonesia Stock Exchange. This research uses stocks of manufacturing sector companies as the object of research. The sampling of the research was conducted by proportional random sampling method and the number of samples of this study were 31 companies obtained from the Indonesia Stock Exchange website from 2012 until 2016. Hypothesis testing is done by path analysis method with the help of SPSS program. The results of the study found that (1) Inflation has a negative and significant effect on the Stock Return, (2) Leverage has a negative and significant effect on Stock Return, (3) Profitability has a positive and significant effect on Stock Return, (4) Inflation has negative and insignificant influence on Profitability, (5) Leverage has a negative and significant influence on Profitability, (6) Profitability is not able to mediate the influence of Inflation on Stock Return, (7) Profitability able to mediate the influence of Leverage on Stock Return.
\end{abstract}

Keywords: Inflation, Leverage, Profitability, Stock Return 


\section{PENDAHULUAN}

Pasar modal memiliki peran penting dalam menunjang perekonomian, karena pasar modal dapat menghubungkan pihak yang membutuhkan dana dengan pihak yang mempunyai kelebihan dana. Disamping itu pasar modal dapat mendorong terciptanya alokasi dana yang efisien, karena dengan adanya pasar modal makapihak yang kelebihan dana (investor) dapat memilih alternatif investasi yang memberikan return yang paling optimal (Tandelilin, 2010:26).

Menurut Tandelilin (2010), investasi adalah komitmen atas sejumlah dana atau sumberdaya lainnya yang dilakukan pada saat ini, dengan tujuan memperoleh sejumlah keuntungan dimasa depan. Jogiyanto (2016) mendefinisikan kegiatan investasi padapasar modal adalah kegiatan menempatkan dana padasatu atau lebih selama periode tertentu dengan harapan dapat memperoleh pendapatan atau peningkatandana atas nilai investasiawal yang bertujuan untuk memaksimalkan return yang diharapkan.

Menurut Jogiyanto (2013:235), return saham adalah nilai yang diperoleh sebagai hasil dari aktivitas investasi. Return merupakan tujuan utama investor untuk mendapatkan hasil dari investasi yang dilakukan oleh investor. Dengan adanya return saham yang cukup tinggi akan lebih menarik para investor untuk membeli saham tersebut. Kinerja keuangan yang baik dari sebuah perusahaan merupakan pertimbangan utama bagi investor. Semakin baik tingkat kinerja keuangan suatu perusahaan maka diharapkan harga saham meningkat dan akan memberikan keuntungan (return) bagi investor. 
Harga saham di bursa sangat dipengaruhi oleh faktor fundamental yaitu kondisi makro dan mikro perusahaan. Terdapat banyak faktor yang mempengaruhi hargadan return saham, baik yang bersifat makromaupun mikro ekonomi. Faktor makro ada yangbersifat ekonomi maupun nonekonomi. Faktor makroekonomi terinci dalam beberapa variabel ekonomi, misalnya inflasi, sukubunga, kurs, tingkat pertumbuhanekonomi, harga bahan bakar minyak di pasar internasional, dan indeks saham regional. Faktor makro nonekonomi meliputi peristiwapolitik domestik, peristiwa sosial, peristiwahukum, dan peristiwa politik internasional. Sementara itu, faktor mikroekonomi meliputi beberapa variabel, misalnya laba persaham, deviden persaham, nilai buku persaham, leverage ratio, dan rasio keuangan lainnya.

Salah satu faktor eksternal yang mempengaruhi return saham adalah inflasi. Menurut Sukirno (2010:14), inflasi merupakan suatu proses kenaikan harga-harga yang berlaku dalam sesuatu perekonomian. Inflasi mengakibatkan menurunnya daya beli masyarakat. Tingkat inflasi suatu negara akan menunjukkan risiko investasidan hal ini akan sangat mempengaruhi perilaku investor dalam melakukan kegiatan investasi.

Tandelilin (2010) menjelaskan bahwa inflasi meningkatkan pendapatan dan biaya perusahaan. Peningkatan biaya produksi yang lebih tinggi dari peningkatan hargajual yang didapat oleh perusahaan akan berdampak pada turunnya profitabilitas perusahaan, begitu juga sebaliknya apabila peningkatan biaya produksi lebih rendah dari peningkatan harga jual perusahaan (produsen) maka profitabilitas perusahaan akan naik. Naik atau turunnya 
profitabilitas perusahaan akan berpengaruh terhadap harga saham dan keinginan investor untuk menanamkan modalnya.

Harga saham saja tidak cukup digunakan oleh investor untuk menilailayak atau tidaknya mereka akan berinvestasi di suatu perusahaan. Investor juga melihat kinerja keuangan perusahaan. Analisis profitabilitas merupakan salah satu cara yang dapat digunakan untuk mengukur kinerja keuangan perusahaan (Kasmir, 2013:197). Menurut Kasmir (2013) rasio profitabilitas merupakan rasio yang digunakan untuk menilai kemampuan perusahaan dalam mencari keuntungan.

Penelitian yang dilakukan oleh Lina (2006) dan Zainudin (2012) menunjukkan profitabilitas berpengaruh positif dan signifikan terhadap return saham, sedangkan hasil penelitian yang dilakukan oleh Zahro (2012) menunjukkan pengaruh negatif profitabilitas terhadap return saham. Perbedaan hasil yang ditunjukkan oleh penelitian tersebut menunjukkan perlu adanya penelitian lebih lanjut mengenai pengaruh profitabilitas terhadap return saham dimana dalam penelitian ini variabel profitabilitas akan dijadikan sebagai variabel mediasi.

Hasil dari penelitian yang dilakukan oleh Lifang (2010) dan Zainudin (2012) menyatakan bahwa Inflasi berpengaruh negatif dan signifikan terhadap return saham. Hasil penelitian yangdilakukan oleh Febrina (2009) mengenai inflasi juga menyatakan bahwa inflasi berpengaruh negatif terhadap profitabilitas. Berbeda dengan hasil penelitian yang dilakukan oleh Paul (2012) dan Aviral (2015) menyatakan bahwa inflasi mempunyai pengaruh yang positif dan signifikan terhadap return saham. Begitu juga dengan penelitianyang dilakukan oleh Wibowo (2013) dan Desi (2012) mengenai hubungan inflasi dengan 
profitabilitas yang menyatakan bahwa inflasi tidak berpengaruh signifikan terhadap profitabilitas.

Berdasarkan perbedaan hasil penelitian yang didapat pada penelitian diatas mengenai pengaruh inflasi terhadap profitabilitas dan return saham, perlu kiranya dilakukan penelitian lebih lanjut mengenai variabel mikroekonomi yang mempengaruhi profitabilitas dan return saham. Variabel mikroekonomi yang digunakan dalam penelitian ini adalah leverage ratio.

Debt to Equity Ratio (DER) merupakan rasio yang digunakan untuk mengukur tingkat leverage dalam menunjukkan kemampuan perusahaan untuk memenuhi kewajiban jangka panjang, yang mana DER menghubungkan antara total debt dengan total ekuitas. Hal ini berarti seberapa besar sumber pendanaan perusahaan yang bergantung pada hutang perusahaan.

Penelitian sebelumnya yang meneliti tentang pengaruh leverage terhadap profitabilitas dan return saham menunjukkan hasil yang berbeda. Ludijanto (2014) dan Warrad (2014) menunjukkan hasil positif dan signifikan tentang pengaruh leverage terhadap profitabilitas, namun berbeda dengan yang dihasilkan oleh Martono (2002) dan Marlina (2015) yang menghasilkan hubungan negatif.

Objek yang digunakan dalam penelitian ini adalah industri manufaktur yang terdaftar di BEI. Harga saham yang fluktuatif dalam 5 tahun terakhir pada saham-saham sektor manufaktur menjadi dasar pengambilan saham-saham sektor manufaktur sebagai objek penelitian ini. Alasan lain sektor industri manufaktur dipilih menjadi obyek penelitian karena sektor manufaktur merupakan sektor yang 
bergerak di bidang pembuatan produk kemudian dijual untuk memperoleh profit yangbesar. Untuk mencapai tujuan tersebut diperlukan modal yang besar dari berbagai sumber dan manajemen dengan tingkat efektifitas yang tinggi.

Adapun rumusan masalah dalam penelitian ini adalahsebagai berikut:

1) Apakah inflasi berpengaruh signifikan terhadap return saham?

2) Apakah leverage berpengaruh signifikan terhadap return saham?

3) Apakah profitabilitas berpengaruh signifikan terhadap return saham?

4) Apakah inflasi berpengaruh signifikan terhadap profitabilitas?

5) Apakah leverage berpengaruh signifikan terhadap profitabilitas?

6) Apakah profitabilitas mampu memediasi pengaruh inflasi terhadap return saham?

7) Apakah profitabilitas mampu memediasi pengaruh leverage terhadap return saham?

\section{LANDASAN TEORI}

\section{Teori Penilaian Saham}

Perhitungan nilai suatu aset dapat dilakukan dengan bermacammacam metode. Terdapat dua pendekatan yang digunakan investor untuk menganalisis dan menilai harga saham, yaitu analisis teknikal dan analisis fundamental. Analisis teknikal lebih menekankan pada pola penggerakan harga berdasarkan datapasar masa lalu, sedangkan analisis fundamental menekankan analisisnya pada variabel ekonomi, industri dan perusahaan (Gitman, 2010:273). 


\section{Analisis Teknikal}

Analisa teknikal adalah suatu jenis analisa yang selalu berorientasi kepada harga pembukaan, harga penutupan, harga tertinggi dan harga terendah dari suatu instrumen investasi dan pada time frame tertentu. Perubahan harga cenderung bergerak pada suatu arah tertentu (trend), pola tertentu dimasa yang lampau akan terulang kembali pada masayang akan datang. Analisisteknikal lebih memperhatikan pada apa yang telahterjadi di pasar, daripada apa yang seharusnya terjadi. Analisis teknikal mempunyai asumsi bahwa harga suatusaham akan ditentukan oleh permintaan dan penawaran terhadap saham tersebut, sehingga asumsi yang mendasari analisis teknikal, antara lain (Tandelilin, 2010:248):

1) Nilai pasar barang dan jasa ditentukan oleh interaksi permintaan dan penawaran.

2) Interaksi permintaan dan penawaran ditentukan oleh berbagai faktor, baik faktor rasional maupun faktor yang tidak rasional. Faktor-faktor tersebut meliputi berbagai variabel makroekonomi dan variabel fundamental serta faktor seperti opini yang beredar, mood investor dan ramalan investor.

3) Harga-harga sekuritassecara individu dan nilai pasar secara keseluruhan cenderung bergerak mengikuti suatu tren selama jangka waktu yang relatif panjang.

4) Tren perubahan hargadan nilai pasar dapat berubah karena perubahan permintaan dan penawaran. Hubungan-hubungan tersebut akan dideteksi dengan melihatdiagram reaksi pasar yang terjadi. 


\section{Analisis Fundamental}

Analisis fundamental merupakan analisis mengenai ekonomi, industri dan kondisi perusahaan untuk memperhitungkan nilaidari saham perusahaan. Analisis fundamental memperkirakan hargasaham dimasa yang akan datang dengan mengestimasinilai faktor-faktor fundamental yang mempengaruhi harga saham dimasayang akan datang dan menerapkan hubungan variabel-variabel sehingga diperoleh taksiran hargasaham.

Menurut Tandelilin (2010:338), analisis fundamental dapat dilakukan secara top down approach melalui tiga tahapan, yaitu:

\section{1) Analisis Ekonomi}

Analisis ekonomi merupakan analisis terhadap faktor-faktor eksternal berupa peristiwa yang terjadi di luar perusahaan dan mempengaruhi semua perusahaan, sehingga tidak dapat dikendalikan oleh perusahaan.

\section{2) Analisis Industri}

Analisi industri diperlukan untuk mengetahui kelemahan dan kekuatan jenis industri perusahaan yang bersangkutan. Hal-hal penting yang perlu dipertimbangkan seperti penjualan dan laba perusahaan, kebijakan pemerintah, kondisi persaingan dan harga saham perusahaan sejenis.

\section{3) Analisis Perusahaan}

Analisis perusahaan digunakan untuk mengetahui kinerja perusahaan. Para penanam modal memerlukan informasi tentang perusahaan yang relevan 
sebagai dasar pembuatan keputusan investasi. Informasi tersebut baik informasi internal dan eksternal perusahaan.

\section{Teori Signal (Signaling Theory)}

Menurut Brigham dan Houston (2009) isyarat atau signal adalah suatu tindakan yang diambil perusahaan untuk memberi petunjukbagi investor tentangbagaimana manajemen memandang prospek perusahaan. Sinyal ini berupa informasi mengenai apa yang sudah dilakukan oleh manajemen untuk merealisasikan keinginan pemilik. Informasi tersebut penting bagi investor karena informasi pada hakekatnya menyajikan keterangan, catatan atau gambaran, baik untuk keadaanmasa lalu, saat ini maupun masa yang akan datang dan bagaimana efeknyapada perusahaan.

\section{HIPOTESIS}

\section{1) Pengaruh Inflasi terhadap Return Saham}

Inflasi merupakan kecenderungan kenaikan harga barang-barang secara umum yang terjadi terus menerus. Hal ini akan mempengaruhi kenaikan biaya produksi suatu perusahaan. Biaya produksi yangtinggi tentu saja akan membuat harga jual barang naik, sehingga akan menurunkan jumlah penjualan yangakan berdampak buruk terhadap kinerjaperusahaan. Hal ini akan menurunkan minat investor terhadap saham tersebut yang akan menyebabkan turunnya return saham perusahaan tersebut. Hasil dari penelitian mengenai pengaruh inflasi terhadap 
return saham yang dilakukan oleh Lifang (2010) dan Zainudin (2012) menyatakan bahwa inflasi berpengaruh negatif signifikan terhadap return saham.

H1: Inflasi memiliki pengaruh negatif signifikan terhadap return saham

\section{2) Pengaruh Leverage terhadap Return Saham}

Leverage merupakan alat untuk mengukur seberapa besar perusahaan tergantung pada kreditur dalam membiayai aset perusahaan. Penelitian ini menggunakan rasio utang dengan ekuitas (Debt to Equity Ratio) untuk mengukur leverage. Rasio leverage yang tinggi menunjukkan kinerja perusahaan yang semakinburuk, karena tingkat ketergantungan permodalan perusahaan terhadap pihak luar semakin besar. Apabila DER perusahaan tinggi, maka harga saham perusahaan cenderung akan rendah. Hal ini disebabkan jika perusahaan memperoleh laba, perusahaan cenderung untuk menggunakan laba tersebut untuk membayar utangnya dibandingkan dengan membagi dividen (Dharmastuti, 2004). Penelitan yang meneliti tentang pengaruh leverage terhadap return saham yang diteliti oleh Caskey (2011), Johnson (2011), Hwang (2010), dan Lina (2016) yang mendapatkan hasil pengaruh negatif antara leverage dan return saham.

H2: Leverage memiliki pengaruh negatif signifikan terhadap return saham

\section{3) Pengaruh Profitabilitas terhadap Return Saham}

Penelitian ini menggunakan Return on Asset (ROA) sebagai rasio profitabilitas. Return on Asset (ROA) mencerminkan seberapa banyak perusahaan telah memperoleh hasil atas seluruh sumberdaya keuangan yang ditanamkanpada perusahaan. Tingginya tingkat profitabilitas (ROA) meningkatkan 
kemampuan perusahaan dalam menstabilkan keadaan keuangan perusahaan. Semakin besarnya daya tarik perusahaan menjadikan semakin banyak investor yang menginginkan saham perusahaan tersebut. Jika permintaan atas saham suatu perusahaan semakin banyak maka harga sahamnya akan meningkat. Penelitian mengenai pengaruh profitabilitas terhadap return saham yang dilakukan oleh Lina (2016) dan Zainudin (2012) mendapatkan hasil positif signifikan antara profitabilitas terhadap return saham.

H3: Profitabilitas memiliki pengaruh positif signifikan terhadap return saham

\section{4) Pengaruh Inflasi terhadap Profitabilitas}

Inflasi dapat berpengaruh buruk bagi perekonomian. Hal ini dapat mengakibatkan minat masyarakat untuk menabung, atau berinvestasi danberproduksi menjadi berkurang. Harga meningkat dengan cepat, masyarakat tidak sanggup mengimbangi harga kebutuhansehari-hari yang terus meningkat. Bagi perusahaan, sebuah inflasi menyebabkan naiknya biaya produksi dan operasional mereka sehingga pada akhirnya merugikan perusahaan itu sendiri. Inflasi dapat meningkatkan pendapatandan biaya perusahaan. Jika peningkatan biaya produksi lebih tinggi dari peningkatan harga yang dapat dinikmati oleh perusahaan maka profitabilitas perusahaan akan turun (Tandelilin, 2010). Hasil penelitian yang dilakukan oleh Febrina (2009) mengenai hubungan inflasi dengan profitabilitas menyatakan bahwa inflasi berpengaruh negatif terhadap profitabilitas.

H4: Inflasi memiliki pengaruh negatif signifikan terhadap profitabilitas 


\section{5) Pengaruh Leverage terhadap Profitabilitas}

Rasio leverage menekankan peran penting utang bagi perusahaan dengan melihat persentase aktiva perusahaan yang didukung oleh utang. Berdasarkan Pecking Order Theory, perusahaan dengan laba yang bertumbuh mempunyai kesempatan yang profitable dalam mendanai investasinya secara internal sehingga perusahaan menghindar untuk menarik dana dari luar dan berusaha mencari solusi yang tepat atas masalah-masalah yangterkait dengan hutangnya. Hutang mempunyai dampak yang buruk terhadap kinerja perusahaan, karena tingkat hutang yang semakin tinggi berarti beban bunga akan semakinbesar yang artinya mengurangi keuntungan. Semakin tinggi Leverage menunjukkan semakin besar beban perusahaan terhadap pihak luar, hal ini sangatmemungkinkan menurunkan kinerja perusahaan. Maka pengaruh antara Leverage dengan Profitabilitas adalah negatif (Brigham dan Houston, 2009:98). Penelitian sebelumnyayang meneliti tentang pengaruh Leverage terhadapProfitabilitas yang dilakukan oleh Martono (2002) dan Marlina (2015) menunjukkan hasil yang negatif dan signifikan.

H5: Leverage memiliki pengaruh negatif signifikan terhadap profitabilitas

\section{6) Profitabilitas sebagai pemediasi pengaruh Inflasi terhadap Return Saham}

Inflasi yang tinggi akan mengakibatkan penurunan harga saham karena menyebabkan kenaikan harga barang secara umum. Kondisi ini mempengaruhi biaya produksi dan harga jual barang akan menjadi semakin tinggi. Inflasi yang tinggi akan menyebabkan menurunnya daya beli, hal ini akanmempengaruhi 
keuntungan perusahaan dan akhirnya berpengaruh terhadap harga saham yang mengalami penurunan. Kenaikan tingkat Inflasi menjadikan harga-harga barang atau bahanbaku mempunyai kecenderunganyang meningkat juga. Peningkatan harga barang dan bahan baku ini akan membuat biaya produksi tinggi, sehingga akan berpengaruhpada penurunan jumlah permintaan secara individual maupun menyeluruh. Penurunan jumlah permintaan ini pada akhirnya akan menurunkan pendapatan dan profitabilitas perusahaan sehingga akan berpengaruh pada return yang diterima perusahaan. Dalam hal ini, profitabilitas berperan sebagai pemediasi pengaruh inflasi terhadap return saham. Hasil penelitian yang dilakukan oleh Febrina (2009) mengenai hubungan inflasi dengan profitabilitas menyatakan bahwa inflasi berpengaruh negatif terhadap profitabilitas. Berbeda dengan penelitian yang dilakukan oleh Lina (2016) dan Zainudin (2012) mendapatkan hasil positif signifikan mengenai pengaruh profitabilitas terhadap return saham.

H6: Profitabilitas mampu memediasi pengaruh Inflasi terhadap Return Saham

\section{7) Profitabilitas sebagai pemediasi pengaruh Leverage terhadap Return}

\section{Saham}

Tingkat Debt to Equity Ratio yang tinggi menunjukkan komposisi total hutang semakin besar apabila dibandingkan dengan total modal sendiri, sehingga hal ini akan berdampak pada semakin besar pula beban perusahaan terhadap para kreditur. DER yang terlalu tinggi mempunyai dampak buruk terhadap kinerja perusahaan, karena tingkat hutang yang semakin tinggi berarti beban bunga 
perusahaan akan semakin besar dan mengurangi keuntungan perusahaan. Keuntungan perusahaan yang menurun serta beban bunga perusahaan yang meningkat menyebabkan profitabilitas perusahaan ikut terpengaruh. Peningkatan beban terhadap kreditur akan menunjukkan sumber modal perusahaan sangat tergantung dari pihak eksternal, sehingga mengurangi minat investor dalam menanamkan dananya di perusahaan yang bersangkutan. Penurunanminat investor dalam menanamkan dananya ini akan berdampak pada penurunan harga saham perusahaan, sehingga return perusahaan juga semakin menurun. Leverage yang tinggi akan menyebabkan penurunan Profitabilitas dan Return Saham. Namun, perusahaan dapat mengoptimalkan keuntungan yang didapat dengan efektif dan efisien untuk mengelola hutang tersebut sehingga Leverage yang tinggi tidak berpengaruh signifikan terhadap penurunan Return Saham. Dalam hal ini, Profitabilitas dapat berperan sebagai pemediasi pengaruh Leverage terhadap Return Saham. Penelitian sebelumnya yang meneliti tentang pengaruh leverage terhadap profitabilitas yang dilakukan oleh Martono (2002) dan Marlina (2015) menunjukkan hasil yang negatif dansignifikan. Sedangkan penelitian mengenai pengaruh profitabilitas terhadap return saham mendapatkan yang dilakukan oleh Lina (2016) dan Zainudin (2012) mendapatkan hasil positif signifikan antara profitabilitas terhadap return saham.

H7: Profitabilitas mampu memediasi pengaruh Leverage terhadap Return Saham 
Berdasarkan penjelasan diatas, maka dapat digambarkan kerangka konseptual penelitian adalah sebagai berikut:

\section{Gambar 1}

\section{Kerangka Konseptual}

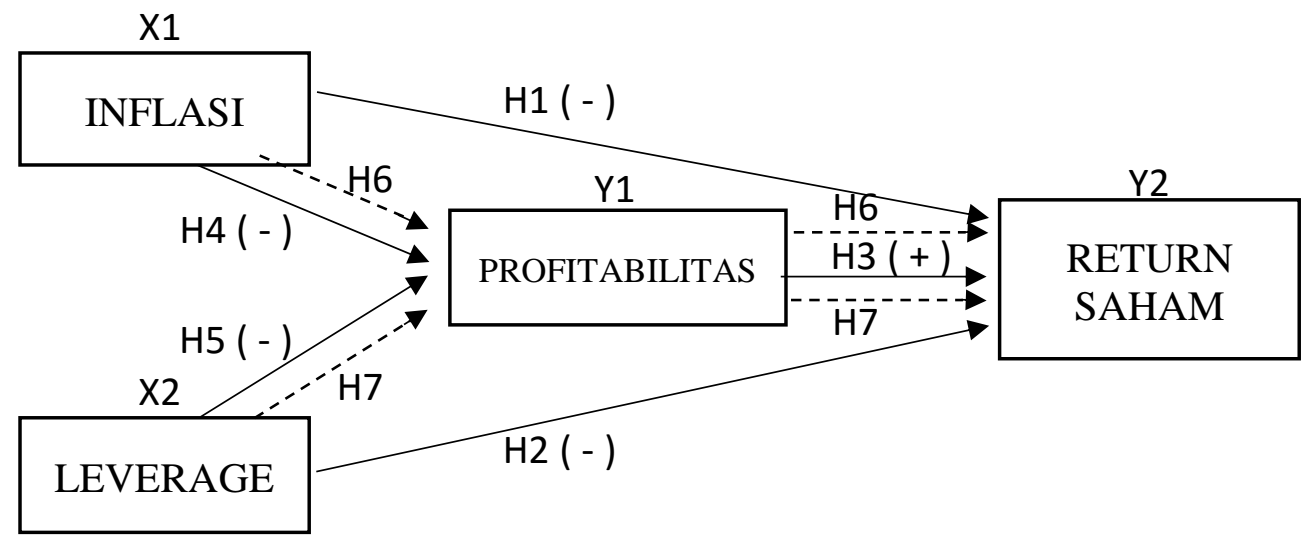

Keterangan:

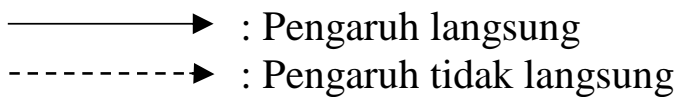

\section{METODE PENELITIAN}

Penelitian ini merupakan penelitian jenis asosiatif dengan hubungan kausal dimana terdapat variabel bebas dan terikat. Variabel eksogen dalam penelitian ini adalah Inflasi (X1) dan Leverage (X2), yang menjadi variabel mediasi adalah Profitabilitas (Y1), dan yang menjadi variabel endogen adalah Return Saham (Y2).

Penelitian ini menggunakan data kuantitatif dan kualitatif pada periode tahun 2012-2016. Data-data tersebut merupakan data sekunder yang bersumber dari website Bursa Efek Indonesia, Bank Indonesia, dan Yahoo! Finance. Data yang digunakan dalam penelitian ini yaitu harga saham per triwulan, tingkat inflasi per triwulan, total hutang per triwulan, total ekuitas per triwulan, laba bersih setelah 
pajak per triwulan, dan total aktiva per triwulan. Penggunaan data per triwulan dimaksudkan agar terdapat variasi dalam data penelitian. Data per triwulan juga untuk menyesuaikan kepada periode laporan keuangan yang dipublikasikan oleh perusahaan-perusahaan yangterdaftar di Bursa Efek Indonesia, dimana data total hutang, total ekuitas, laba bersih setelah pajak, dan total aktiva didapatkan dari laporan keuangan perusahaan.

Populasi yang digunakan pada penelitian ini adalah perusahaan manufaktur yang selalu terdaftar di Bursa Efek Indonesia periode 2012-2016. Metode pengambilan sampel yang digunakan adalah metode Proportional Random Sampling. Metode ini menghendaki cara pengambilan sampel dari tiap-tiap sub populasi dengan memperhitungkan besarkecilnya sub-sub populasi tersebut. Cara ini dapat memberi landasan generalisasi yanglebih dapat dipertanggungjawabkan daripada apabila tanpa memperhitungkan besar kecilnya tiap-tiap sub populasi. Dalam penelitian ini, sampel yang diambil adalah 25 persen untuk setiap sub populasi atau sub sektor dari sektor manufaktur. Dari total populasi 126 saham perusahaan manufaktur yang selalu terdaftar di Bursa Efek Indonesia periode 2012-2016, didapatkan sampel sebanyak 31 saham yang terdiri dari 14 saham dari sub sektor industri dasar dan kimia, 9 saham dari sub sektor aneka industri, dan 8 saham dari sub sektor industri barang konsumsi.

Analisis data yang digunakan dalam penelitian ini adalah Analisis Jalur (Path Analysis) untuk mengetahui pengaruh antar variabel dan Uji Sobel untuk mengetahui pengaruh mediasi dari variabel mediasi. 


\section{HASIL DAN PEMBAHASAN}

\section{Analisis Deskriptif}

Statistik deskriptif memberikan informasi tentang karakteristik variabel penelitian antara lain nilai minimum, nilai maksimum, mean serta standar deviasi. Hasil statistik deskriptif dari data adalah sebagai berikut:

\section{Tabel 5.1}

Statistik Deskriptif Variabel Inflasi, Rasio Leverage, Rasio Profitabilitas, dan Return Saham

\begin{tabular}{lccccc}
\hline & $\mathbf{N}$ & Minimum & Maximum & Mean & Std. Deviation \\
\hline Inflasi & 620 & 3.02 & 8.40 & 5.5205 & 1.79937 \\
Leverage & 620 & -1.73 & 152.49 & 1.7249 & 6.37990 \\
Profitabilitas & 620 & -.41 & .26 & .0332 & .05450 \\
Return & 620 & -.51 & 1.74 & .0331 & .22864 \\
Valid N (listwise) & 620 & & & & \\
\hline Sumber: Output SPSS & & & & &
\end{tabular}

Tabel 5.1 menunjukkan jumlah data yang digunakan dalam penelitian ini berjumlah 620 sampel data. Berdasarkan perhitungan selama periode pengamatan, dapat terlihat bahwa Inflasi (X1) memiliki rata-rata hitung (mean) sebesar 5,52. Standar deviasi (simpangan baku) variabel Inflasi adalah sebesar 1,79. Nilai minimum dalam periode pengamatan adalah sebesar 3,02 dan maksimum adalah sebesar 8,40 persen. Variabel Leverage (X2) yang diproksikan dengan Debt to Equity Ratio (DER) memiliki mean sebesar 1,72. Nilai standar deviasi sebesar 6,37, serta nilai minimum Leverage adalah sebesar -1,73 dan nilai maksimumnya adalah sebesar 152,49. Variabel Profitabilitas (Y1) yang diproksikan dengan Return on Asset (ROA) memiliki nilai rata-rata (mean) adalah sebesar 0,03, dengan standar deviasi sebesar 0,05 persen, dengan nilai ROA minimum sebesar $-0,41$ dan nilai maksimum sebesar 0,26. Variabel Return Saham (Y2) memiliki rata-rata hitung 
(mean) sebesar 0,03. Standar deviasi Return Saham adalah sebesar 0,22. Nilai Return Saham terendah adalah sebesar-0,51, sedangkan Return Saham tertinggi yaitu sebesar 1,74 .

\section{Hasil Analisis Jalur (Path Analysis)}

Berdasarkan hubungan antar variabel secara teoritis, dapat dibuat model dalam bentuk diagram path sebagai berikut :

Gambar 5.1

Model Analisis Jalur

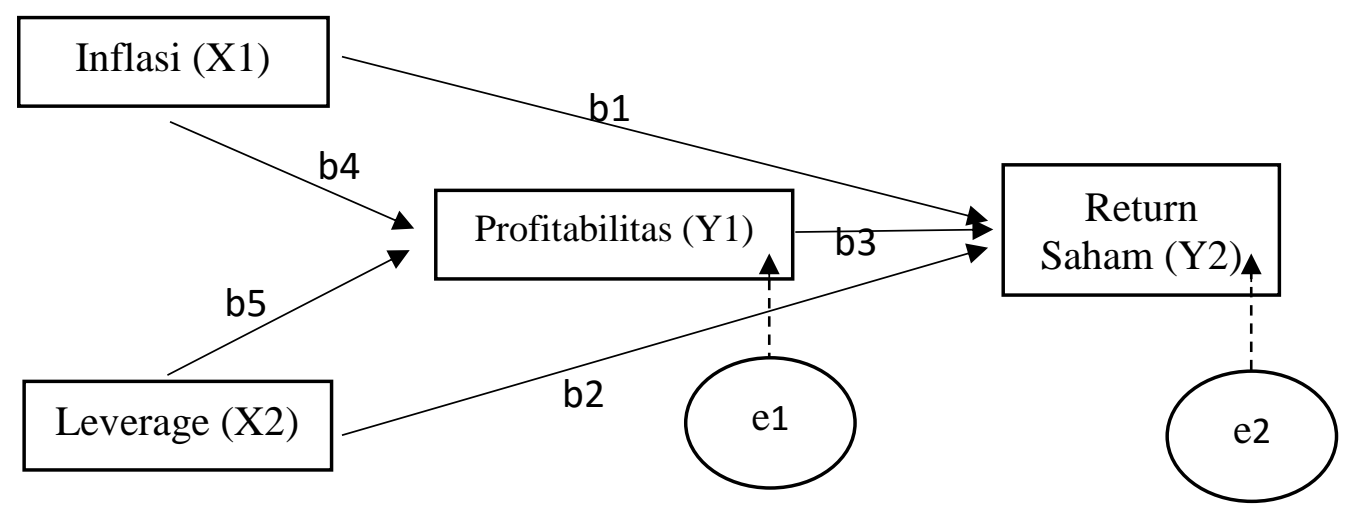

Berdasarkan gambar diatas, untuk mengetahui pola hubungan masing-masing variabel, disusun sistem persamaan atau model struktural sebagai berikut:

a. Hubungan kausal antar variabel X1 dan X2 terhadap Y1

$$
\mathrm{Y}_{1}=\mathrm{b}_{4} \mathrm{X}_{1}+\mathrm{b}_{5} \mathrm{X}_{2}+\mathrm{e}_{1}
$$

b. Hubungan antar variabel $\mathrm{X}_{1}, \mathrm{X}_{2}$, dan $\mathrm{Y}_{1}$ terhadap $\mathrm{Y}_{2}$

$$
\mathrm{Y}_{2}=\mathrm{b}_{1} \mathrm{X}_{1}+\mathrm{b}_{2} \mathrm{X}_{2}+\mathrm{b}_{3} \mathrm{Y}_{1}+\mathrm{e}_{2}
$$


Tabel 5.2

Persamaan Koefisien Jalur Inflasi dan Leverage terhadap Profitabilitas

\begin{tabular}{|c|c|c|c|c|c|c|}
\hline \multirow[b]{2}{*}{ Model } & & \multicolumn{2}{|c|}{ Unstandardized Coefficients } & \multicolumn{2}{|l|}{$\begin{array}{l}\text { Standardized } \\
\text { Coefficients }\end{array}$} & \multirow[b]{2}{*}{ Sig. } \\
\hline & & B & Std. Error & Beta & $\mathrm{t}$ & \\
\hline \multirow[t]{3}{*}{1} & (Constant) & .042 & .007 & & 6.147 & .000 \\
\hline & Inflasi & -.001 & .001 & -.036 & -.925 & .355 \\
\hline & Leverage & -.002 & .000 & -.215 & -5.453 & .000 \\
\hline
\end{tabular}

a. Dependent Variable: Profitabilitas

Dari tabel 5.2 didapatkan persamaan sebagai berikut:

$$
Y_{1}=-0,036 X_{1}-0,215 X_{2}+e_{1}
$$

Tabel 5.3

Persamaan Koefisien Jalur Inflasi, Leverage, dan Profitabilitas terhadap Return Saham

\begin{tabular}{|c|c|c|c|c|c|c|}
\hline \multirow[b]{2}{*}{ Model } & & \multicolumn{2}{|c|}{ Unstandardized Coefficients } & \multicolumn{2}{|l|}{$\begin{array}{l}\text { Standardized } \\
\text { Coefficients }\end{array}$} & \multirow[b]{2}{*}{ Sig. } \\
\hline & & $\mathrm{B}$ & Std. Error & Beta & $\mathrm{t}$ & \\
\hline \multirow[t]{4}{*}{1} & (Constant) & .478 & .128 & & -3.743 & .000 \\
\hline & Inflasi & -.212 & .021 & -.199 & -9.892 & .000 \\
\hline & Leverage & -.252 & .006 & -.839 & -40.749 & .000 \\
\hline & Profitabilitas & 1.786 & .723 & .051 & 2.471 & .014 \\
\hline
\end{tabular}

a. Dependent Variable: Return

Dari tabel 5.3 didapatkan persamaan sebagai berikut:

$$
\mathrm{Y}_{2}=-0,199 \mathrm{X}_{1}-0,839 \mathrm{X}_{2}+0,051 \mathrm{Y}_{1}+\mathrm{e}_{2}
$$

\section{Pendugaan Parameter atau Koefisien Jalur (path)}

Perhitungan koefisien pada analisis jalur mengunakan perhitungan regresi variabel dibakukan (standardize coeffcient beta), secara parsial pada masing- 
I Gede Putra Adyatmika dan I Gusti Bagus Wiksuana, Pengaruh Inflasi dan Leverage...

masing persamaan. Sehingga dari hasil perhitungan akan diperoleh pengaruh langsung, pengaruh tidak langsung, dan pengaruh total. Pengaruhnya dapat dihitung sebagai berikut:

Tabel 5.4

Nilai Pengaruh Langsung, Pengaruh Tidak Langsung, dan Pengaruh Total Antar Variabel

\begin{tabular}{|c|c|c|c|c|}
\hline Pengaruh Variabel & $\begin{array}{l}\text { Pengaruh } \\
\text { Langsung }\end{array}$ & $\begin{array}{c}\text { Pengaruh } \\
\text { Tidak } \\
\text { Langsung }\end{array}$ & Pengaruh Total & Keterangan \\
\hline $\begin{array}{l}\text { Inflasi (X1) } \rightarrow \\
\text { Return Saham (Y2) }\end{array}$ & $-0,199$ & $\begin{array}{l}-0,036 \times 0,051 \\
=-0,0018\end{array}$ & $\begin{array}{l}-0,199-0,0018= \\
-0,2008\end{array}$ & Signifikan \\
\hline $\begin{array}{l}\text { Leverage }(\mathrm{X} 2) \rightarrow \\
\text { Return Saham }(\mathrm{Y} 2)\end{array}$ & $-0,839$ & $\begin{array}{l}-0,215 \times 0,051 \\
=-0,011\end{array}$ & $\begin{array}{l}-0,839-0,011 \\
=-0,85\end{array}$ & Signifikan \\
\hline $\begin{array}{l}\text { Profitabilitas (Y1) } \\
\rightarrow \text { Return Saham } \\
\text { (Y2) }\end{array}$ & 0,051 & - & 0,051 & Signifikan \\
\hline $\begin{array}{l}\text { Inflasi }(\mathrm{X} 1) \rightarrow \\
\text { Profitabilitas (Y1) }\end{array}$ & $-0,036$ & - & $-0,036$ & $\begin{array}{l}\text { Tidak } \\
\text { Signifikan }\end{array}$ \\
\hline $\begin{array}{l}\text { Leverage }(\mathrm{X} 2) \rightarrow \\
\text { Profitabilitas }(\mathrm{Y} 1)\end{array}$ & $-0,215$ & - & $-0,215$ & Signifikan \\
\hline
\end{tabular}

Sumber: Lampiran 1, data diolah.

\section{Perhitungan Standard Error of Estimate dan Total Variasi yang Dijelaskan}

Terdapat indikator validitas model di dalam regresi, yaitu koefisien determinasi $\left(\mathrm{R}^{2}\right)$. Koefisien determinasi $\left(\mathrm{R}^{2}\right)$ dapat dilihat pada tabel berikut:

Tabel 5.5

Hasil Pengujian Koefisien Determinasi Inflasi dan Leverage Terhadap Profitabilitas

\begin{tabular}{ccccc}
\hline Model & R & R Square & $\begin{array}{c}\text { Adjusted } \\
\text { R Square }\end{array}$ & $\begin{array}{c}\text { Std. Error of } \\
\text { the Estimate }\end{array}$ \\
\hline 1 & $.221^{\mathrm{a}}$ & .049 & .046 & .05324 \\
\hline Sumber: Output SPSS & & &
\end{tabular}

Tabel 5.5 menunjukkanbahwa koefisien determinasi dengan nilai R2 sebesar 0,049 yang berarti 4,9 persen variasi Profitabilitas dapat dijelaskan oleh 
variasi variabel Inflasi dan Leverage, sedangkan sisanya sebesar 95,1 persen dijelaskan olehvariabel lain yang tidak diteliti dalam penelitian.

\section{Tabel 5.6}

Hasil Pengujian Koefisien Determinasi Inflasi, Leverage, dan Profitabilitas Terhadap Return Saham

\begin{tabular}{|c|c|c|c|c|}
\hline Model & $\mathbf{R}$ & R Square & $\begin{array}{l}\text { Adjusted } \\
\text { R Square }\end{array}$ & $\begin{array}{l}\text { Std. Error of } \\
\text { the Estimate }\end{array}$ \\
\hline 1 & $867^{\mathrm{a}}$ & .752 & .751 & .95555 \\
\hline
\end{tabular}

Tabel 5.6 menunjukkan bahwa koefisien determinasi dengan nilai R2 sebesar 0,752 yang berarti 75,2 persen variasi Return Saham dapat dijelaskan oleh variasi variabel Inflasi, Leverage, dan Profitabilitas, sedangkansisanya sebesar 24,8 persen dijelaskan oleh variabel lain yang tidak diteliti dalam penelitian.

Standard Error of Estimate dari model regresi bisa dihitung sebagai berikut:

$$
\begin{array}{ll}
\mathrm{P}_{\mathrm{e} 1}=\sqrt{1-R^{2}} & \mathrm{P}_{\mathrm{e} 2}=\sqrt{1-R^{2}} \\
\mathrm{P}_{\mathrm{e} 1}=\sqrt{1-0.049} & \mathrm{P}_{\mathrm{e} 2}=\sqrt{1-0,752} \\
\mathrm{P}_{\mathrm{e} 1}=\sqrt{0.951} & \mathrm{P}_{\mathrm{e} 2}=\sqrt{0.248} \\
\mathrm{P}_{\mathrm{e} 1}=0.975 & \mathrm{P}_{\mathrm{e} 2}=0.498
\end{array}
$$

Perhitungan Koefisien Determinasi Total adalah sebagai berikut:

$$
\begin{aligned}
& \mathrm{R}_{\mathrm{m}}^{2}=1-\mathrm{P}_{\mathrm{e} 1}{ }^{2} \mathrm{P}_{\mathrm{e} 2}{ }^{2} \\
& \mathrm{R}^{2}{ }_{\mathrm{m}}=1-(0.975)^{2}(0.498)^{2} \\
& \mathrm{R}^{2}{ }_{\mathrm{m}}=1-0.2356 \\
& \mathrm{R}_{\mathrm{m}}^{2}=0.7644
\end{aligned}
$$


Dari hasil perhitungan koefisiendeterminasi total diatas diperoleh nilai Rm2 sebesar 0,7644 yang berarti sebesar 76,44 persen informasi yang terkandung dapat dijelaskan melalui model yang telah dibentuk, sedangkan sisanya sebesar 23,56 persen dijelaskan melalui variabel diluar model yang dibentuk.

\section{Gambar 5.2}

Nilai Hubungan Inflasi, Leverage, Profitabilitas, dan Return Saham

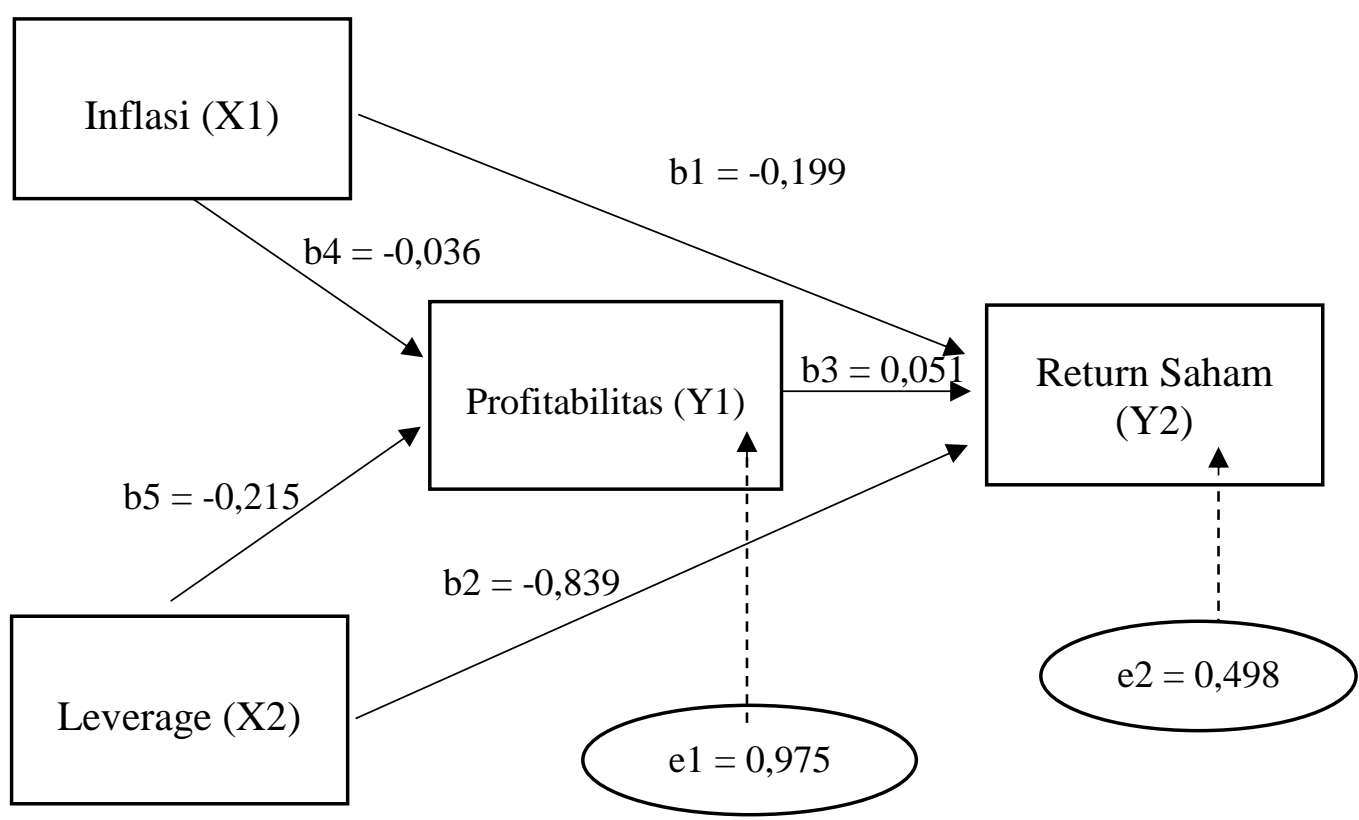

\section{Hasil Uji Sobel}

Pengaruh tidak langsung Inflasi terhadap Return Saham lewat Profitabilitas dihitung dengan cara mengalikan jalur Inflasi-Profitabilitas (a) dengan jalur Profitabilitas-Return Saham (b) atau jalur ab. Nilai pengaruh tidak langsungnya (c') adalah $-0.036 \times 0.051=-0.001836$.

Perhitungan standard error pengaruh tidak langsung antara Inflasi dan Return Saham yang dimediasi oleh Profitabilitas adalah sebagai berikut: 


$$
\begin{array}{ll}
\mathrm{Sab}=\sqrt{b^{2} S a^{2}+a^{2} S b^{2}+S a^{2} S b^{2}} & \mathrm{z}=\frac{\mathrm{ab}}{\mathrm{Sab}} \\
\mathrm{Sab}=\sqrt{0.000004235} & \mathrm{z}=\frac{-0.001786}{0.002057973} \\
\mathrm{Sab}=0.002057973 & \mathrm{z}=-0.8678
\end{array}
$$

Nilai z hitung pengaruh tidak langsung antara Inflasi dan Return Saham yang dimediasi oleh Profitabilitas adalah sebesar -0.8678 .

Pengaruh tidak langsung Leverage terhadap Return Saham lewat Profitabilitas dihitung dengan cara mengalikan jalur Leverage-Profitabilitas (a) dengan jalur Profitabilitas-Return Saham (b) atau jalur ab. Nilai pengaruh tidak langsungnya (c') adalah $-0.215 \times 0.051=-0.010965$.

Perhitungan standard error pengaruh tidak langsung antara Leverage dan Return Saham yang dimediasi oleh Profitabilitas adalah sebagai berikut:

$$
\begin{array}{ll}
\mathrm{Sab}=\sqrt{b^{2} S a^{2}+a^{2} S b^{2}+} S a^{2} S b^{2} & \mathrm{z}=\frac{\mathrm{ab}}{\mathrm{Sab}} \\
\mathrm{Sab}=\sqrt{0.000002507} & \mathrm{z}=\frac{-0.003572}{0.0015835} \\
\mathrm{Sab}=0.001583 & \mathrm{z}=-2.25572
\end{array}
$$

Nilai z hitung pengaruh tidak langsung antara Leverage dan Return Saham yang dimediasi oleh Profitabilitas adalah sebesar -2.25572. 


\section{Hasil Pengujian Hipotesis}

Hasil pengujian variabel Inflasi terhadap Return Saham menghasilkan nilai $\mathrm{T}$ hitung sebesar -9,892 dengan nilai signifikansi sebesar 0,000. Nilai signifikansi $0,000<0,05$ berarti hipotesis $1(\mathrm{H} 1)$ yaitu Inflasi memiliki pengaruh negatif signifikan terhadap return saham diterima yang menunjukkan bahwa Inflasi berpengaruh negatif signifikan terhadap Return Saham.

Hasil pengujian variabel Leverage terhadap Return Saham menghasilkan nilai T hitung sebesar $-40,749$ dengan nilai signifikansi sebesar 0,000. Nilai signifikansi $0,000<0,05$ berarti hipotesis $2(\mathrm{H} 2)$ yaitu Leverage memiliki pengaruh negatif signifikan erhadap return saham diterima yang menunjukkan bahwa Leverage berpengaruh negatif signifikan terhadap Return Saham.

Hasil pengujian variabel Profitabilitas terhadap Return Saham menghasilkan nilai T hitung sebesar 0,051 dengan nilai signifikansi sebesar 0,014. Nilai signifikansi $0,014<0,05$ berarti hipotesis $3(\mathrm{H} 3)$ yaitu Profitabilitas memiliki pengaruhpositif signifikan terhadap return saham diterima yang menunjukkan bahwa Profitabilitas berpengaruh positif signifikan terhadap Return Saham.

Hasil pengujian variabel Inflasi terhadap Profitabilitas menghasilkan nilai T hitung sebesar -0,925 dengan nilai signifikansi sebesar 0,355. Nilai signifikansi 0,355 > 0,05 berarti hipotesis $4(\mathrm{H} 4)$ yaitu Inflasi memiliki pengaruh negatif signifikan terhadap profitabilitas ditolak yang menunjukkan bahwa Inflasi berpengaruh negatif dan tidak signifikan terhadap Profitabilitas. 
Hasil pengujian variabel Leverage terhadap Profitabilitas menghasilkan nilai $\mathrm{T}$ hitung sebesar $-5,453$ dengan nilai signifikansi sebesar 0,000. Nilai signifikansi $0,000<0,05$ berarti hipotesis $5(\mathrm{H} 5)$ yaitu Leverage memiliki pengaruh negatif signifikan terhadap profitabilitas diterima yang menunjukkan bahwa Leverage berpengaruh negative dan signifikan terhadap Profitabilitas.

Nilai pengaruh tidak langsung Inflasi terhadap Return Saham melalui Profitabilitas (c') adalah sebesar -0.001836. Nilai pengaruh langsung Inflasi terhadap Return Saham tanpa melalui Profitabilitas (c) sebesar -0.199. Nilai z hitung pengaruh tidak langsung antara Inflasi dan Return Saham yang dimediasi oleh Profitabilitas adalah sebesar -0.8678 . Nilai $-0.8678<1.96$ berarti hipotesis 6 (H6) yaitu Profitabilitas mampu memediasi pengaruh Inflasi terhadap Return Saham ditolak yang menunjukkan bahwa Profitabilitas tidak mampu memediasi pengaruh Inflasi terhadap Return Saham.

Nilai pengaruh tidak langsung Leverage terhadap Return Saham melalui Profitabilitas (c') adalah sebesar -0.010965. Nilai pengaruh langsung Leverage terhadap Return Saham tanpa melalui Profitabilitas (c) sebesar -0.839. Nilai z hitung pengaruh tidak langsung antara Leverage dan Return Saham yang dimediasi oleh Profitabilitas adalah sebesar -2.25572 . Nilai $2.25572>1.96$ berarti hipotesis 7 (H7) yaitu Profitabilitas mampu memediasi pengaruh Leverage terhadap Return Saham diterima yang menunjukkan bahwa Profitabilitas mampu memediasi pengaruh Inflasi terhadap Return Saham. 


\section{Pembahasan Hasil Penelitian}

\section{Pengaruh Inflasi terhadap Return Saham}

Hasil penelitian menunjukkan bahwa Inflasi berpengaruh negatif dan signifikanterhadap Return Saham. Hal ini menunjukkan bahwa peningkatan harga barang-barang serta bahanbaku akan membuat biaya produksi dan harga jual barang menjadi tinggi sehingga akan berpengaruh pada penurunan jumlah permintaan yang berakibat pada penurunanpenjualan. Hal ini menguatkan teori kuantitasyang menyatakan bahwa harga barang berbandinglurus dengan jumlah uang yang beredar. Teori ini menyatakanbahwa terjadinya inflasi disebabkan oleh satufaktor yaitu kenaikan uang yang beredar. Inflasi berpengaruh negatif terhadap Return Saham perusahaan manufaktur disebabkan Inflasi akan meningkatkan biaya produksi dan operasional perusahaan. Peningkatan biaya ini akan mempengaruhi keuntungan perusahaan dan penurunan minat investor akan saham perusahaan tersebut sehingga akhirnya berpengaruh terhadap harga dan return saham yang mengalami penurunan. Hasil penelitian ini mendukung hasil penelitian sebelumnya yaitu Lifang (2010) dan Zainudin (2012) yang menyatakanbahwa Inflasi berpengaruh negatif dan signifikan terhadap Return Saham.

\section{Pengaruh Leverage terhadap Return Saham}

Hasil penelitian menunjukkan bahwa Leverage berpengaruh negatif dan signifikan terhadap Return Saham. Hal ini menunjukkan bahwa tingkat DER yang tinggi menunjukkan komposisi total hutang semakinbesar apabila dibandingkan dengan total modal sendiri, sehingga hal ini akan berdampak pada semakin besar 
pula beban perusahaan terhadap pihak eksternal (para kreditur) dalam memenuhi kewajiban hutangnya. Menurut Signalling Theory, informasi yang dipublikasikan sebagai suatu pengumuman akan memberikan signal bagi investor dalam pengambilan keputusan investasi. Tingginya beban perusahaan akan mengurangi minatinvestor dalam menanamkan dananya di perusahaan yangbersangkutan. Hal ini menunjukkan bahwa informasi perubahan DER yang dapat diperoleh dari laporan keuangan perusahaan berpengaruh pada keputusan atas harga saham di pasarmodal. Hasil penelitian ini mendukung penelitian sebelumnya yaitu Caskey (2011), Johnson (2011), Hwang (2010), dan Lina (2016) yang menyatakan bahwa Leverage berpengaruh negatif dan signifikan terhadap Return Saham.

\section{Pengaruh Profitabilitas terhadap Return Saham}

Hasil penelitian menunjukkan bahwa Profitabilitas berpengaruh positif dan signifikan terhadap Return Saham. Profitabilitas yang semakin meningkat memperlihatkan kemampuan perusahaandalam menghasilkan laba semakin tinggi dan hal ini dapat dikategorikan sebagai sinyal yang baik karena mengindikasikan kondisi perusahaan yang baik. Profitabilitas yang tinggi menunjukkan perusahaan efektif dalam pengelolaan asetnya dan mempunyai prospek yang baik, sehingga investor akan meresponpositif sinyal tersebut dan nilai perusahaan akan meningkat. Hal ini sesuai dengan Signalling Theory yang menyatakan bahwa salahsatu jenis informasi yang dikeluarkan oleh perusahaandapat menjadi sinyal bagi pihak luar perusahaan, terutama bagi investor. Hasil penelitian ini mendukung penelitian sebelumnya yaitu Lina (2016) dan Zainudin (2012) yang menyatakan bahwa Profitabilitas berpengaruh positif dan signifikan terhadap Return Saham. 


\section{Pengaruh Inflasi terhadap Profitabilitas}

Hasil penelitian menunjukkan bahwa Inflasi berpengaruh negatif dan tidaksignifikan terhadap Profitabilitas. Hal ini menunjukkan bahwa meskipun Inflasi mengalami kenaikan, namun laba yangdiperoleh perusahaan tidak mengalami penurunan yang signifikan dan sebaliknya. Alasan yang menjelaskan kondisi tersebut adalahbahwa pada dasarnya inflasi yang tinggi mencerminkan kenaikan harga barang-barang yangmenjadikan nilai uang dapat berkurang akibat harga yang meningkat. Hal ini mengakibatkanminat masyarakat untukmenabung, atau berinvestasi dan berproduksi menjadi berkurang. Tandelilin (2010) menjelaskan bahwa Inflasi meningkatkan pendapatan dan biayaperusahaan. Jika peningkatan biaya produksi lebih tinggi dari peningkatan hargayang dilakukan oleh perusahaan maka profitabilitas perusahaan akan turun. Namun demikian, dampak negatif dari inflasi terhadap profitabilitas nampaknya belum signifikan pada taraf $5 \%$. Hal ini dapat disebabkan oleh kenaikan biaya produksi dan operasional perusahaan diimbangi oleh kenaikan harga jual produk yang dihasilkan oleh perusahaan sehingga penurunan laba yang dialami oleh perusahaan tidak terlalu tinggi. Hasil penelitian mendukung penelitian sebelumnya yaitu Wibowo (2013) dan Desi (2012) yang menyatakan bahwa Inflasi berpengaruh negatif dan tidak signifikan terhadap Profitabilitas.

\section{Pengaruh Leverage terhadap Profitabilitas}

Hasil penelitian menunjukkan bahwa Leverage berpengaruh negatif dan signifikan terhadap Profitabilitas. Semakin tinggi DER menunjukkan komposisi 
totalhutang semakin besar dibanding dengan total modalsendiri, sehingga berdampak semakin besar beban perusahaan terhadap pihak luar (kreditur). DER yang tinggi akan menurunkan Profitabilitas perusahaan karena meningkatnya biaya bunga dan resiko gagalbayar. Apabila hal tersebut terjadi, maka akan berdampak pada penurunan Profitabilitas perusahaan sebagai akibat dari penggunaan hutang perusahaan yang besar, sehingga menyebabkan biaya tetap yang harus ditanggung perusahaan lebih besar dari operating income yang dihasilkan dari hutang tersebut. Hasil penelitian ini mendukung hasil penelitian sebelumnya yang dilakukan oleh Martono (2002) yang mendapatkan hasil negatif tidak signifikan dan Marlina (2015) yang menunjukkan hasil negatif dan signifikan mengenai pengaruh Leverage terhadap Profitabilitas.

\section{Profitabilitas tidak mampu memediasi pengaruh Inflasi terhadap Return}

\section{Saham}

Hasil pengujian menunjukkan bahwa Profitabilitas tidak mampu memediasi pengaruh Inflasi terhadap Return Saham karena nilai z hitung tidak lebih besar dari nilai z tabel. Inflasi memiliki pengaruh langsung yang negatif dansignifikan terhadap Return Saham. Inflasi juga mempunyai pengaruh negatif dan tidak signifikan terhadap Profitabilitas. Ketidakmampuan Profitabilitas memediasi pengaruh Inflasi terhadap Return Saham dikarenakan perubahan Profitabilitas tidak berdampak signifikan terhadap pengaruh Inflasi terhadap Return Saham. Profitabilitas yang diproksikan dengan ROA yang dipublikasikan pada laporan keuangan kurang informatif bagi investor dalam mengestimasi ReturnSaham. Investor tidak merespon ROA sebagai informasi atau sinyal yang bisa mengubah 
ketertarikan mereka terhadap suatu saham, sehingga tidak mempengaruhi Return Saham tersebut. Hal ini menunjukkan bahwa investor tidak semata-mata menggunakan ROA sebagai ukuran dalam menilai kinerja perusahaan untuk memprediksi Return Saham di pasar modal.

\section{Profitabilitas mampu memediasi pengaruh Leverage terhadap Return Saham}

Hasil pengujian menunjukkan bahwa Profitabilitas mampu memediasi pengaruh Leverage terhadap Return Saham karena nilai z hitung lebih besar dari nilai z tabel. Pengaruh Leverage terhadap Return Saham baik secara langsung maupun secara tidak langsung melalui Profitabilitas tetap sama yaitu negatif dan signifikan. Hal ini menunjukkan Profitabilitas mampu memediasi pengaruh Leverage terhadap Return Saham secara parsial. Perubahan Profitabilitas perusahaan yang diproksikan dengan ROA berdampak signifikan terhadap pengaruh Leverage terhadap Return Saham perusahaan manufaktur. Investor menganggap informasi mengenai Profitabilitas perusahaan mampu mengubah perusahaan yang mempunyai Leverage tinggi akan mempunyai Return Saham yang baik. Hal ini mengindikasikan investor lebih percaya terhadap informasi mengenai Profitabilitas perusahaan daripada tingkat Leverage akan mempengaruhi Return Saham perusahaan manufaktur.

\section{SIMPULAN DAN SARAN}

Berdasarkan hasil penelitian dapat disimpulkan Inflasi berpengaruh negatif dan signifikan terhadap Return Saham, Leverage berpengaruh negatif dan 
signifikan terhadap Return Saham, Profitabilitas berpengaruh positif dan signifikan terhadap Return Saham, Inflasi berpengaruh negatif dan tidak signifikan terhadap Profitabilitas, Leverage berpengaruh negatif dan signifikan terhadap Profitabilitas, Profitabilitas tidak mampu memediasi pengaruh Inflasi terhadap Return Saham, dan Profitabilitas mampu memediasi pengaruh Leverage terhadap Return Saham.

Adapun saran yang dapat diberikan berkaitan dengan penelitian ini sebagai berikut yaitu bagi perusahaan diharapkan hasil penelitian ini dapat membantu perusahaan untuk mengetahui bagaimana Inflasi dan Leverage dapat mempengaruhi Profitabilitas dan Return Saham. Perusahaan diharapkan dapat mengantisipasi Inflasi yang terjadi dan dapat mengoptimalkan Leverage sehingga dapat meningkatkan Profitabilitas dan Return Saham Perusahaan. Bagi investor dan calon investor yang akan menginvestasikan dananya di pasar modal, diharapkan hasil penelitian ini dapat membantu dalam menentukan strategi investasinya di pasar modal dengan lebih memperhatikan tingkat Inflasi yang sedang terjadi, Leverage, dan Profitabiltas perusahaan. Bagi peneliti selanjutnya disarankan untuk menggunakan periode penelitian yang lebih panjang, sampel yang digunakan dalam penelitian selanjutnya diharapkan menggunakan seluruh sampel yang terdaftar di BEI sehingga diperoleh hasil yang lebihbaik lagi, dan memperluas ruanglingkup penelitian, baik itu dengan perluasan subjek penelitian maupun dengan memperhatikan variabel-variabel lain yang mempengaruhi Return Saham. 


\section{REFERENSI}

Alagidede, Paul \& Panagiotidis, Theodore. 2012. Stock returns and inflation: Evidence from quantile regression. Economics Letters 117 283-286

Auliyah, R dan Hamzah, A. 2006. Analisa Karakteristik Perusahaan, Industridan Ekonomi Makro Terhadap Return dan Beta SahamSyariah di Bursa Efek Jakarta. JurnalSimposium NasionalAkuntansi Vol. 9. Hal. 23-26.

Bodie, Z., Kane, A., \& Marcus, A. J. 2010. Essentials of Investment. Singapore. McGraw Hill.

Brigham, Eugene F. Daves, Philip R. 2007. IntermediateFinancial Management, $9^{\text {th }}$ Edition, Thomson, South-Western.

Brigham, Eugene F. and Gapenski, Louis C. and Daves, P.R. 1999. Intermediate Financial Management, Fifth Edition. USA. TheDryden PressHarcourt Brace College Publisher.

Brigham, E.F., Houston, J.F. 2009. Fundamentals of Financial Management. 10th Edition. Harcourt.

Caskey, Judson et al. 2011. Leverage, Excess Leverage, and Future Returns. Rev Account Stud 17:443-471

Dharmastuti, Fara. 2004. Analisis Pengaruh Faktor-Faktor Keuangan Terhadap Harga Saham Perusahaan Go Publik di BEJ. Jurnal ManajemenFakultas Ekonomi Universitas Atmajaya Vol 1 No. 1. Hal. 44-61.

Dwijayanthy, Febrina \& Naomi, Prima. 2009. Analisis Pengaruh Inflasi, BI Rate, dan Nilai Tukar Mata Uang terhadap Profitabilitas BankPeriode 20032007. Karisma Vol. 3 (2): 87-98.

Fahmi, I. 2012. Pengantar Pasar Modal. Bandung. Alfabeta.

George, T., \& Hwang, C. 2010. A resolution of the distress risk and leverage puzzles in the cross section of stock returns. Journal of Financial Economics, 96, 56-79.

Ghozali, Imam. 2013. Aplikasi Analisis Multivariate dengan Program SPSS. Edisi Ketujuh. Semarang. Badan Penerbit Universitas Diponegoro.

Gitman, L. J. 2010. Principles of Manajerial Finance International Edition. Boston. Pearson Edition.

Halim, Abdul. 2005. Analisis Investasi. Edisi Kedua. Jakarta. Salemba Empat. 
Hanafi, M. Mamduh \& Halim, Abdul. 2016. Analisis Laporan Keuangan Edisi 5. Yogyakarta: UPP STIM YKPN.

Iba, Zainuddin \& Wardhana, Aditya. 2012. Pengaruh Inflasi, Suku Bunga SBI, Nilai Tukar Rupiah Terhadap USD, Profitabilitas, dan Pertumbuhan Aktiva terhadap Harga Saham Perusahaan Pembiayaan di Bursa Efek Indonesia. Jurnal Kebangsaan, Vol. I No.1 Januari 2012. Hal. 1-6.

Jin-Soo, Lee dan Soo Cheong, Jang. 2007. The systematic-risk determinants of the US airline industry. Tourism Management Volume 28, Issue 2, April 2007, Hal. 434-442.

Jogiyanto. 2013. Teori Portofolio dan Analisis Investasi. Edisi Kesepuluh. Cetakan Kedua, Yogyakarta: BPFE.

Johnson, T.C. et al. 2011. Endogenous leverage and expected stock returns. Finance Research Letters 8 132-145

Kasmir. (2013) Bank dan Lembaga Keuangan Lainnya. Jakarta. Rajawali Pers.

Li, Lifang et al. 2010. An analysis of inflation and stock returns for the UK. Int. Fin. Markets, Inst. and Money 20 519-532

Ludijanto, Shella Ekawati, Handayani, Siti Ragil, dan Hidayat, Raden Rustam. 2014. Pengaruh Analisis Leverage terhadap Kinerja Keuangan Perusahaan (Studi pada Perusahaan Property dan Real Estate yang Listing di BEI Tahun 2010-2012). Jurnal Administrasi Bisnis, Vol. 8 No.1, hal. 1-8. Universitas Brawijaya, Malang.

Mariani, Ni Luh Lina, Fridayana Yudiaatmaja, dan Ni Nyoman Yulianthini. 2016. Pengaruh Profitabilitas Dan Leverage Terhadap Return Saham. e-Journal Bisma Universitas Pendidikan Ganesha Jurusan Manajemen (Volume 4 Tahun 2016)

Martono, Cyrillius. 2002. Analisis Pengaruh Profitabilitas Industri, Rasio Leverage Keuangan Tertimbang dan Intensitas Modal Tertimbang Serta Pangsa Pasar terhadap "ROA" Dan "ROE" Perusahaan Manufaktur yang GoPublic di Indonesia. Jurnal Akuntansi \& Keuangan. Vol. 4 No. 2, hal. 126-140

Min, Teng et al. 2016. Banking relationship, relative leverage and stock returns in Japan. Pacific-Basin Finance Journal 40 (2016) 86-101

Putong, Iskandar. 2010. Economics: Pengantar Mikro dan Makro Edisi 5. Ghalia Indonesia. 
Rachmawati, Dewi dan Wahyudi, Sugeng. 2012. Analisis Pengaruh Rasio Keuangan dan Makro Ekonomi Terhadap Harga Saham Pada Perusahaan LQ 45 Yang Terdaftar di BEI Tahun 2007-2011. Diponegoro Journal of Management. Vol 1, No 1, Hal. 1-11.

Sugiyono. 2015. Metode Penelitian Kuantitatif Kualitatif dan R\&D. Bandung. Alfabeta.

Sukirno, Sadono. 2010. Ekonomi Pembangunan: Proses, Masalah, dan Dasar Kebijakan. Jakarta. Penerbit Kencana Prenada Media Group.

Swandayani, Desi Marilin \& Kusumaningtias, Rohmawati. 2012. Pengaruh Inflasi, Suku Bunga, Nilai Tukar Valas Dan Jumlah Uang Beredar Terhadap Profitabilitas Pada Perbankan Syariah Di Indonesia Periode 2005-2009. Jurnal Akuntansi AKRUAL 3 (2) hal. 147-166

Tandelilin., Eduardus 2010. Analisis Investasi dan Manajemen Portofolio. Edisi Pertama. Yogyakarta. BPFE

Tiwari, Aviral Kumar et al. 2015. Stock returns and inflation in Pakistan. Economic Modelling 47 23-31

Warrad, Lina et al. 2013. The Impact of Profitability on Obtaining Debt Through The Financial Leverage: Comparative Study among Industrial Sectors in Jordan. Interdisciplinary Journal of Contemporary Research in Bussiness, Vol. 5 No.3, pp 25-34. UK.

Wibowo, Edhi Satriyo \& Syaichu, Muhammad. 2013. Analisis Pengaruh Suku Bunga, Inflasi, CAR, BOPO, NPF Terhadap Profitabilitas Bank Syariah. Diponegoro Journal of Management Volume 2, Nomor 2, Tahun 2013, Halaman 1-10.

Widiyanti, Marlina \& Elfina, Friska Dwi. 2015. Pengaruh Financial Leverage terhadap Profitabilitas pada Perusahaan Sub Sektor Otomotif dan Komponen yang Terdaftar di Bursa Efek Indonesia. Jurnal Manajemen dan Bisnis Sriwijaya Vol.13 No.1 Maret 2015 hal. 117-136.

Yuliaty, Erma. 2008. Pengaruh PER, PBV, NPM, GPM, dan DER terhadapReturn Saham periode Pengamatan 2001-2005. Jurnal Ekonomidan Bisnis, Vol. 13 No. 2 hal. 54-59.

Zahro, Nafi' Inayati. 2012. PengaruhRasio ProfitabilitasTerhadap Return Saham Perusahaan Manufaktur Yang Terdaftar di Bursa Efek Indonesia. Jurnal Universitas Muria Kudus Vol. 5 No.1. Hal. 34-41. 